\title{
How to Survey About Electoral Turnout? Additional Evidence
}

\author{
Alexandre Morin-Chassé*
}

Post-election surveys measure voter turnout in a variety of ways. The Canadian Election Study (CES) simply asks respondents whether or not they voted. However, existing research shows that some abstainers report having voted when they in fact did not (Granberg and Holmberg, 1991; Selb and Munzert, 2013). If this misreporting is correlated with other traits, analysis based on the data can be biased. One possible solution to reduce the incentive to overreport is to reframe the turnout question.

The British Election Study presents respondents with a short preamble (SP) before asking them if they voted or not. Such SPs state that some people abstain at elections, and that they do so for a variety of reasons. No published study has ever tested if including a SP impacts on reported behavior. The CES fielded an experiment in its online survey following the 2015 federal election to answer this very question.

The survey was conducted by the firm Survey Sampling International (SSI). Small monetary incentives were used to encourage participation. Unfortunately, SSI's recruitment methods make it impossible to compute a response rate. ${ }^{1} 7,557$ Rs participated in the pre-election telephone survey, and 4,408 also completed the online post-election survey (attrition rate : 41.7\%). A random half of Rs was exposed to a SP before being asked whether or not they voted (see Table 1). The SP mentions: "some people are not able to vote because they are sick or busy, or for some other reason. Others do not want to vote." Experimental groups are balanced on observable characteristics. Non-response items are recoded as missing data $(\approx 2 \%)$.

\footnotetext{
The data, code, and any additional materials required to replicate all analyses in this article are available at the Journal of Experimental Political Science Dataverse within the Harvard Dataverse Network, at: doi:10.7910/DVN/RHPOYR. Thanks to Semra Sevi, Alexandre Blanchet, Eric Lachapelle, Damien Bol, Laura Stephenson, and anonymous referees for comments and suggestions.

*University of Montreal e-mail: alexandre.morin.chasse@umontreal.ca

${ }^{1}$ See appendix and Breton et al. (2017) for explanations.
}

(c) The Experimental Research Section of the American Political Science Association 2018 
Table 1

Experimental Conditions in the Short Preamble Experiment

\begin{tabular}{|c|c|c|}
\hline Component & Control condition & Treatment condition \\
\hline Preamble & (None) & $\begin{array}{l}\text { The federal election was held on Monday, } \\
\text { October } 19 . \text { In any election, some people } \\
\text { are not able to vote because they are sick } \\
\text { or busy, or for some other reason. Others } \\
\text { do not want to vote. }\end{array}$ \\
\hline Question & Did you vote in the election? & Did you vote in the recent federal election? \\
\hline Response options & $\begin{array}{l}\text { (1) Yes (2) No (3) Don’t } \\
\text { know (4) Refuse to answer }\end{array}$ & $\begin{array}{l}\text { (1) Yes (2) No (3) Don't know (4) Refuse to } \\
\text { answer }\end{array}$ \\
\hline
\end{tabular}

Table 2

Results for the Short Preamble Experiment

\begin{tabular}{|c|c|c|c|c|c|c|}
\hline & \multicolumn{2}{|c|}{$\begin{array}{l}\text { Control group (without } \\
\text { short preamble) }\end{array}$} & \multicolumn{2}{|c|}{$\begin{array}{l}\text { Treatment group (with } \\
\text { short preamble) }\end{array}$} & \multirow{2}{*}{$\begin{array}{l}\text { Difference in } \\
\text { percentage } \\
\text { points }\end{array}$} & \multirow[b]{2}{*}{$p$-value } \\
\hline & $N$ & $\%$ Voted & $N$ & $\%$ Voted & & \\
\hline Disabilities: Yes & 339 & 89.1 & 287 & 83.3 & -5.8 & 0.034 \\
\hline Disabilities: No & 1,771 & 87.9 & 1,797 & 87.7 & -0.2 & 0.845 \\
\hline All sample & 2,188 & 87.9 & 2,146 & 87.0 & -0.9 & 0.377 \\
\hline
\end{tabular}

Table 3

Experimental Conditions in the Face-Saving Response Items Experiment

\begin{tabular}{|c|c|c|}
\hline Component & Control condition & Treatment condition \\
\hline Preamble & $\begin{array}{l}\text { In each election, we found } \\
\text { that a lot of people were } \\
\text { not able to vote because } \\
\text { they were not } \\
\text { registered, they were } \\
\text { sick, or they did not } \\
\text { have time. }\end{array}$ & $\begin{array}{l}\text { In each election we found that a lot of people were } \\
\text { not able to vote because they were not registered, } \\
\text { they were sick, or they did not have time. }\end{array}$ \\
\hline Question & $\begin{array}{l}\text { Were you personally able } \\
\text { to vote in this election? }\end{array}$ & $\begin{array}{l}\text { Which of the following statements best describes } \\
\text { you? }\end{array}$ \\
\hline $\begin{array}{r}\text { Response } \\
\text { options }\end{array}$ & $\begin{array}{l}\text { (1) Yes (2) No (3) Don’t } \\
\text { know/prefer not to } \\
\text { answer }\end{array}$ & $\begin{array}{l}\text { (1) I did not vote in the election (2) I thought about } \\
\text { voting this time but didn't (3) I usually vote but } \\
\text { didn't this time (4) I am sure I voted in the } \\
\text { election (5) Don't know/prefer not to answer }\end{array}$ \\
\hline
\end{tabular}

Table 2 presents the results. Subgroup analyses show that the SP reduces reported turnout among people with disabilities ( -5.8 percentage points). However, this effect is largely diluted when all Rs are combined. In the whole sample, reported 


\begin{tabular}{|c|c|c|c|c|c|c|c|c|}
\hline Case ID & Year & Region & Level & Observations & Effect Size & P-Value & & \\
\hline 1 & 2015 & Madrid & Regional & 770 & -9.57 & $<.001$ & $\longmapsto$ & ............. \\
\hline 2 & 2015 & Ontario & National & 1431 & -7.57 & $<.001$ & & \\
\hline 3 & 2015 & British Columbia & National & 1330 & -.81 & 0.739 & & 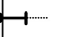 \\
\hline 4 & 2015 & Quebec & National & 1307 & -7.84 & $<.001$ & & \\
\hline 5 & 2014 & Bavaria & Europe & 2399 & -4.46 & .014 & & \\
\hline 6 & 2014 & Provence & Europe & 806 & -14.24 & $<.001$ & & \\
\hline 7 & 2014 & Îles-de-France & Europe & 834 & -17.98 & $<.001$ & & \\
\hline 8 & 2014 & Catalonia & Europe & 811 & -12.23 & .002 & & \\
\hline 9 & 2014 & Madrid & Europe & 805 & -13.68 & .001 & & \\
\hline 10 & 2014 & Lower Saxony & Europe & 791 & -5.93 & .211 & & $+\cdots$ \\
\hline 11 & 2014 & Marseille & Municipal & 517 & -5.99 & .232 & & 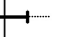 \\
\hline 12 & 2014 & Paris & Municipal & 856 & -7.52 & .019 & & \\
\hline 13 & 2013 & Lower Saxony & Regional & 818 & -5.68 & .152 & & +1 \\
\hline 14 & 2012 & Catalonia & Regional & 800 & -6.75 & .001 & & \\
\hline 15 & 2012 & Quebec & Regional & 724 & -10.00 & $<.001$ & & \\
\hline 16 & 2012 & Provence & National & 719 & -.99 & .820 & & \\
\hline 17 & 2012 & Île-de-France & National & 748 & -.70 & .873 & & \\
\hline 18 & 2011 & Ontario & Regional & 884 & -.19 & .950 & & 巴... \\
\hline 19 & 2011 & Catalonia & National & 818 & -2.41 & .284 & & $+\ldots$ \\
\hline 20 & 2011 & Madrid & National & 823 & -5.99 & .003 & $\leftrightarrow$ & \\
\hline 21 & 2011 & Lucerne & National & 844 & -9.09 & .003 & & \\
\hline 22 & 2011 & Lucerne & Regional & 904 & -12.53 & $<.001$ & 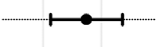 & \\
\hline 23 & 2011 & Zurich & National & 840 & -4.48 & .126 & $\rightarrow$ & 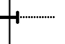 \\
\hline 24 & 2011 & Zurich & Regional & 843 & -8.24 & .005 & $\longmapsto 1$ & \\
\hline Average & & & & 24 & -7.27 & $<.001$ & tor & \\
\hline \multirow[t]{2}{*}{ Combined } & & & & 22422 & -6.82 & $<.001$ & 101 & \\
\hline & & & & & & & $-20 \quad-10$ & 0 \\
\hline
\end{tabular}

Figure 1

Using Face-Saving Response Items to Reduce Vote Overrepporting: Effects Measured in the 24 Survey Experiments Fielded as Part of the Making Electoral Democracy Works Project (95\% CI).

turnout is $87.9 \%$ in the control group, against $87.0 \%$ in the treatment group. This difference is not statistically significant. ${ }^{2}$

The American National Election Studies measure voter turnout using a different approach: they combine a SP with face-saving response items (FSRIs). FSRIs allow respondents to report that they abstained while simultaneously justifying why they did not vote (Duff et al., 2007; Belli et al., 2006).

${ }^{2}$ Actual turnout for this election: $68.3 \%$. Additional information in appendix. 
In a recent publication, Morin-Chassé et al. (2017) present the results of 19 experiments testing the efficacy of replacing yes or no options with FSRIs (see Table 3). In Figure 1, Case IDs 1 to 5 present five additional experiments fielded as part of the same project. ${ }^{3}$ The lines below report the same results as those published before by Morin-Chassé et al. Finally, the two bottom lines present cumulative effect estimates. The first is the average effect size of $(-7.27 \mathrm{pp})$; the second is based on the combination of all individual survey responses $(-6.82 \mathrm{pp})$.

Overall, the findings reported in this Short Report suggest that combining a $\mathrm{SP}$ with FSRIs is a valuable approach to reduce vote overreporting. The main limitation of these experiments is the impossibility to validate self-report data with official voting records.

\section{SUPPLEMENTARY MATERIALS}

The appendix is available online as supplementary material at https://doi.org/ 10.1017/XPS.2018.1

\section{REFERENCES}

Belli, Robert F., Sean E. Moore, and John VanHoewyk. 2006. "An Experimental Comparison of Question Forms Used to Reduce Vote Overreporting." Electoral Studies 25(4): 751-9.

Breton, Charles, Fred Cutler, Sarah Lachance, and Alex Mierke-Zatwarnicki. 2017. "Telephone Versus Online Survey Modes for Election Studies: Comparing Canadian Public Opinion and Vote Choice in the 2015 Federal Election." Canadian Journal of Political Science 50(4): 1005-36.

Duff, Brian, Michael J. Hanmer, Won-Ho Park, and Ismail K. White. 2007. "Good Excuses: Understanding who Votes with an Improved Turnout Question." Public Opinion Quarterly 71(1): 67-90.

Fournier, Patrick, Fred Cutler, Stuart Soroka, and Dietlind Stolle. 2015. "The 2015 Canadian Election Study [dataset].” (http://ces-eec.arts.ubc.ca/english-section/ surveys/).

Granberg, Donald and Soren Holmberg. 1991. "Self-Reported Turnout and Voter Validation." American Journal of Political Science 35(2): 448-59.

Morin-Chassé, Alexandre. 2017. "Replication Data for: How to Survey About Electoral Turnout? Additional Evidence." Harvard Dataverse. V1. doi:10.7910/DVN/RHPOYR.

Morin-Chassé, Alexandre, Damien Bol, Laura B. Stephenson, and Simon Labbé St-Vincent. 2017. "How to Survey About Electoral Turnout? The Efficacy of the Face-Saving Response Items in 19 Different Contexts." Political Science Research and Methods 5(3): 575-84.

Selb, Peter and Simon Munzert. 2013. "Voter Overrepresentation, Vote Misreporting, and Turnout Bias in Postelection Surveys." Electoral Studies 32(1): 186-96.

\footnotetext{
${ }^{3}$ Additional information in appendix.
} 